\title{
Impact of Heap Fermentation of Cocoa on Microbial Dynamics and Soil Physicochemical Parameters
}

\author{
Maboune Tetmoun Suzanne Abeline ${ }^{1,2}$, Tchinmegni Felenou I. ${ }^{2}$, Mfopou Mewouo Yvette Clarisse ${ }^{1}$ and \\ Mounjouenpou Pauline ${ }^{1}$ \\ 1 Institut de Recherche Agricole pour le Développement (IRAD), Yaoundé PO Box: 2067, Cameroon \\ 2 Higher Institute of Environmental Sciences (HIES), Yaoundé PO Box: 16 317, Cameroon
}

Received: April 30, 2015 / Accepted: June 9, 2015 / Published: June 30, 2015.

\begin{abstract}
The overall objective of the present study is to evaluate the impact of the heap fermentation of cocoa on microbial dynamics and physicochemical parameters of the soil. The methodology was to heap fermentation broad beans 600 cocoa pods moved to a place after the soil was taken for microbiological and physicochemical analyzes considered the control sample. In addition, cocoa lixiviate and soil were subjected to analyze. Chemical analysis of cocoa lixiviate revealed the absence of heavy metals such as cadmium, chromium. It appears from the analysis of soil than clays represent on average $46.67 \%, 8.03 \%$ for fine silt, heavy silt $5.69 \%, 15.39 \%$ fine sands and heavy sands $20.02 \%$. Microbiological analysis revealed the abundance of total coliform up to $4.6 \times 103 \mathrm{CFU} / \mathrm{g}$ soil. The variations of the abundance of yeasts are $0.01 \times 103 \mathrm{CFU} / \mathrm{g}$ soil obtained on day 2 at 12 o'clock to $3.5 \times 103 \mathrm{CFU} / \mathrm{g}$ soil observed on day 3 to $18 \mathrm{pm}$ (0-3 cm deep). However, further study on the assessment of biodiversity after the fermentation would determine its species richness.
\end{abstract}

Key word: Cocoa pods, heap fermentation, soil, cocoa lixiviate.

\section{Introduction}

The environment is the set of physical, chemical and biological factors affecting the life and the seed of a plant population, animal or human [1]. It takes into account the soil, air and water and relation with living beings related meteorological events. This is a reporting system in which is accomplished the gigantic recycling of all products of the biosphere, leading to the maintenance of soil, air and water commonly known as biological balance [1]. These balances reflect the activities of producers such as plants, animals as consumers and decomposers such as microorganisms and intervention processes such as oxidation-reduction, precipitation, solubilization and complexation [2]. Numbers of these transformations are carried out on the ground and in an aqueous medium.

Corresponding author: Maboune Tetmoun Suzanne Abeline, MSc., research field: agriculture. E-mail: abmbesso@yahoo.fr, Felenou@gmail.com.
For approximately two decades, Cameroon has adapted a purely industrial strategy to take advantage of these benefits. This strategy seemed to be good in economic terms but in reality, it caused qualitatively (advanced soil infertility) and quantitative (reduced productivity) much damage to Cameroon soils. To dates, the country is trying to add a strategy based on sustainable development focused on three plans: environmental, social and economic. These plans were developed in order to preserve the environment and ensure continuity of sustainable development. The degradation of the environment is a calamity become increasingly critical and worrying recent years [3].

Sustainable development is a concept introduced in 1987 allows reconciling the land development, protection of the environment and allowing reserves for the future generations. With this point of view, most development projects were subjected to prior environmental impact assessment to ensure that 
everything was done to bring out the best alternatives, minimize impacts on the environment or otherwise secure the necessary compensations. The 1996's framework law provides guidance on this for the case of Cameroon while Decree Number 2013/0171 of February 14, 2013 sets out the procedures for carrying out ESIA (environmental and social impact assessment) in Cameroon. The ordinance Number 0070/MINEP of April 22, 2005 lists the projects whose realization was subjected to prior EIA. Thus the heap fermentation of cocoa was performed because of poverty often mentioned by peasant populations. The bean was subsequently used for the sale or processing. Yet this type of fermentation plays an important role in soil. The present study aims to evaluate the impact of the heap fermentation of cocoa on microbial dynamics and soil physicochemical parameters.

\section{Methodology}

Heap fermentation of cocoa was carried out after buying and breaking 600 cocoa pods. Indeed, heap fermentation of cocoa method was chosen because it is the most used by villagers in Cameroon. Cocoa pods were purchased from cocoa farmers. And after that, the pods have been reported in the IRAD (Institute of Agricultural Research for Development) which beans were cleared shell and then left to heap fermentation on the soil. Before that, the soil has been removed and considered as the control sample for microbiological and physicochemical analyzes. In addition, cocoa lixiviate and soil were subjected for analyzes.

\subsection{Microbiological and Physicochemical Analysis}

2.1.1 Soil Collection and Production of Suspensions The soil was taken away to the place of fermentation at two depths in plastic bags, respectively between $0-3$ $\mathrm{cm}$ and 3-20 $\mathrm{cm}$. These depths were chosen because they were the nutrient removal places for young plants. Moreover, soil can be washed away by erosion and be led to the rivers used for irrigation, bath, laundry, the dishes and drinking water. The sampling soil collected in surface $(0-3 \mathrm{~cm})$ was made using a graduated spatula sterilized with alcohol. The one collected in depth $(0-20 \mathrm{~cm})$ was made with the auger also sterilized with alcohol. Every day of heap fermentation of cocoa, 3 samples of each soil depth were collected after an incubation period of $6 \mathrm{~h}$ so as to follow the circadian variation of the selected parameters. The collection times were 6,12 and $18 \mathrm{~h}$. All samples soil collected were kept in a refrigerated chamber and then bring back to the laboratory for analysis.

\subsubsection{Physicochemical Analysis}

The physicochemical parameters of each soil sample analyzed were total nitrogen, organic carbon, extractable cations, cation exchange capacity, soil-pH quality and phosphorus. The Table 1 below shows the parameters analyzed, the devices used and their corresponding standards $[2,4]$.

Table 1 Physicochemical parameters analyzed.

\begin{tabular}{|l|l|l|l|}
\hline Parameters & Methods & Standards & Units \\
\hline Total nitrogen & mineralization (Kjeldahl) and UV-vis spectroscopy & $\begin{array}{l}\text { NF ISO 11261 } \\
\text { (X 31-111) }\end{array}$ & $\mathrm{mg} / \mathrm{kg}$ of soil \\
\hline Organic carbon & $\begin{array}{l}\text { Oxidation sulfochromic (Walkley and Black) and UV-vis } \\
\text { spectroscopy }\end{array}$ & NF ISO 14235 & $\mathrm{mg} / \mathrm{kg}$ of soil \\
\hline $\begin{array}{l}\text { Extractable cations } \\
\left(\begin{array}{l}\text { Exchangeable bases) } \\
\left(\mathrm{Ca}^{2+}, \mathrm{Mg}^{2+}, \mathrm{K}^{+}, \mathrm{Na}^{+}\right)\end{array}\right.\end{array}$ & $\begin{array}{l}\text { Extraction by stirring at } \mathrm{pH} 7 \text { ammonium acetate and } \\
\text { determination by AAS }\end{array}$ & X 31-108 & $\mathrm{mg} / \mathrm{kg}$ of soil \\
\hline $\begin{array}{l}\text { Cationic exchange capacity } \\
(\mathrm{CEC})\end{array}$ & $\begin{array}{l}\text { Extraction by stirring at } \mathrm{pH} 7 \text { ammonium acetate and } \\
\text { determination by AAS }\end{array}$ & X 31-108 & $\mathrm{mg} / \mathrm{kg}$ of soil \\
\hline Soils-pH quality & Electrochemistry 1/5 & NF ISO 10390 & $\mathrm{c} \cdot \mathrm{u}$ \\
\hline Phosphorus & $\begin{array}{l}\text { Solubility in sodium hydrogen carbonate, sodium hydrogen } \\
\text { carbonate }\end{array}$ & NF ISO 11263 & $\mathrm{mg} / \mathrm{kg}$ of soil \\
\hline
\end{tabular}




\subsection{Achievement of Suspensions}

In the laboratory, a quantity of $1 \mathrm{~g}$ of soil sample was weighed using a hypersensitive balance Sartorius brand (MC1 Laboratory Model 620S LC) and then introduced in a test tube containing $\mathrm{NaCl}$ sterile solution in a sterile environment created by the Bunsen burner flame. The mixture is homogenized using a vortex AGT 9 Bunsen brand at increasing speeds and several times to allow a maximum of microorganisms in the soil to be suspended $[5,6]$. The dilutions of the suspensions thus obtained can be performed according to the sample and the group of microorganisms sought until $10^{-6}$ order.

\subsection{Isolation and Enumeration of Total and Fecal Coliforms}

The isolation of total and fecal coliforms were carried out by the membrane filtration technique and spread plate method on XLD (Xylose Lysine Deoxycholate) agar (Scholar). The enumerations were made after 24 to $48 \mathrm{~h}$ incubation at $37^{\circ} \mathrm{C}$ for total coliforms and $44{ }^{\circ} \mathrm{C}$ for faecal coliforms. The results were expressed as colony-forming unit per gram of soil sampled (CFU/g of soil) [7]. Normative references were ISO 93081 and NM 03.07.003 for total coliforms and fecal coliforms respectively.

\subsection{Isolation and Enumeration of Faecal Streptococci}

The isolation of faecal streptococci was performed on Slanetz and Bartley medium (Scholar) cast in petri dishes by the filtration membrane and spread plate methods. After incubation period of $4 \mathrm{~h}$ at $37^{\circ} \mathrm{C}$ and 44 $\mathrm{h}$ of incubation at $44{ }^{\circ} \mathrm{C}$, the purple color of colonies were counted and the results expressed as CFU/g of soil [9]. The normative reference of this method was ISO 7899-2.

\subsection{Isolation and Enumeration of HMB (Heterotrophic Mesophilic Bacteria)}

The isolation of HMB was carried out on PCA (Plate Count Agar) medium (Liofilchem) using spread plate method. After incubation at laboratory temperature (21 $\pm 2{ }^{\circ} \mathrm{C}$ ), the enumerations of all colonies was performed during 5 days [8]. The normative reference this technique was ISO 6222.

\subsection{Isolation and Enumeration of Molds}

Isolation of fungi or yeast was carried out by spreading on the sample on the supplemented chloramphenicol Sabauraud medium (Scholar) using spread plate methods (Pasteur pipette). After incubation at a temperature of $37{ }^{\circ} \mathrm{C}$, the enumeration of all the colonies was performed for $48 \mathrm{~h}$ [8]. Overall, the analyses were performed in triplicate but standard deviations were not fitted because the concentrations recorded microorganisms were too close.

\subsection{Data Analysis}

The variation of the abundances of microorganisms in each experimental condition was illustrated by diagrams. Spearman " $r$ " test correlation was used to assess the degree of correlation between the abundances of mocroorganisms and other parameters considered. Kruskal-Wallis and Mann-Whitney tests were used to compare the mean abundance of microorganisms from one experimental condition to another.

\section{Results}

\subsection{Cocoa Lixiviates Analysis}

The physicochemical analysis of cocoa lixiviate showed the absence of heavy metals such as cadmium, chromium and halogens such as chlorine. However, the authors noted the presence of iron $(5.882 \mathrm{mg} / \mathrm{L})$, zinc (3.438 mg/L) Copper (0.866 mg/L), Manganese (0.578 $\mathrm{mg} / \mathrm{L})$ and Nickel $(0.906 \mathrm{mg} / \mathrm{L})$. Nitrite ions were presented at trace, while the sulfate ions were in abundance. The electrical conductivity was $53 \mu \mathrm{S} / \mathrm{cm}$ and total dissolved solids were $53 \mathrm{mg} / \mathrm{L}$. The chemical oxygen demand of $1,649 \mathrm{mg} / \mathrm{L}$ registered indicates a large amount of organic material in the cocoa lixiviate. Table 2 shows the physicochemical parameters of the analyzed cocoa lixiviate. 


\subsection{Soil Analysis}

Soil analysis was focused on the physical and chemical aspects before and after the heap fermentation of cocoa. On the physical, mechanical analysis showed that the soil of the study area contained clay, silt and sand. Table 3 shows the composition of the soil of the study area at each depth of sampling. It appears that the means soil composition were $46.67 \%$ for clays, $8.03 \%$ for silt, $5.69 \%$ for large silt, $15.39 \%$ for fine sands and $20.02 \%$ for fat sands. The soil humidity as it goes to $3.09 \%$ in the surface to $6.71 \%$ to the depth between 20 and $40 \mathrm{~cm}$.

Chemically, before heap fermentation of cocoa total organic matter of soil analysis ranged from 18.38 to $40.81 \mathrm{~g} / \mathrm{kg}$ of soil. Carbon fluctuated between 8.29 and $23.67 \mathrm{~g} / \mathrm{kg}$ of soil and nitrogen ranged from 0.21 to $1.86 \mathrm{~g} / \mathrm{kg}$ of soil (Table 4). Total phosphorus speed ranged between 4.50 and $25.98 \mathrm{mg} / \mathrm{kg}$ of soil. The concentration of exchangeable acids was zero while that of the originally basics of soil fertility varied from one base to another and from one depth soil to another (Table 4). Generally, soil $\mathrm{pH}$ studied before heap fermentation of cocoa was acid with values below 6.85 uc with an alkalinity less than $6.1 \mathrm{uc}$.

After heap fermentation of the cocoa, the organic matter concentration in the soil decreased in the $0-3 \mathrm{~cm}$ depth, and increased in the $3-20 \mathrm{~cm}$ and $20-40 \mathrm{~cm}$ depths from 16.12 to $14.29 \mathrm{~g} / \mathrm{kg}$ of soil and 19.49 to
$18.38 \mathrm{~g} / \mathrm{kg}$ of soil respectively. Organic carbon and total nitrogen representing $11.31 ; 10.66 \mathrm{~g} / \mathrm{kg}$ of soil and 0.39 and $0.21 \mathrm{~g} / \mathrm{kg}$ soil to depths $3-20 \mathrm{~cm}$ and $20-40 \mathrm{~cm}$ respectively. There is an increase of soil moisture to 0-3 $\mathrm{cm}$ and $3-20 \mathrm{~cm}$ depths. Humidity levels reaching 7.30 and $5.80 \%$ respectively. This increase may be related to the infiltration of cocoa lixiviate in the soil during the fermentation.

Out of the $3-20 \mathrm{~cm}$ depth, the total phosphorus content after fermentation decreases from 25.98 to $11.97 \%$ in $0-3 \mathrm{~cm}$ depth and from 11.97 to $4.50 \%$ in the $3-20 \mathrm{~cm}$ depth. Overall, the concentration of the responsible base soil fertility varies from one base to another and to a depth of soil to the next. The concentration of $\mathrm{CaO}$ reduces in the $0-3 \mathrm{~cm}$ depth from 1.73 to $1.15 \mathrm{~mol} / \mathrm{kg}$ of soil. The same result was observed with $\mathrm{MgO}$ at the same depth. The concentration of $\mathrm{MgO}$ obtained being $0.10 \mathrm{~mol} / \mathrm{kg}$ of soil after heap fermentation of the cocoa. The concentrations of $\mathrm{K}_{2} \mathrm{O}$ pass from 0.26 to $0.052 \mathrm{~mol} / \mathrm{kg}$ in the $3-20 \mathrm{~cm}$ and from 0.30 to $0.079 \mathrm{~mol} / \mathrm{kg}$ in the 20-40 cm depth. The concentrations of $\mathrm{Na}_{2} \mathrm{O}$ decrease at all depths after heap fermentation (Table 4). Soil acidity after heap fermentation of cocoa increases with $\mathrm{pH}$, which mean rose from 6.56 to $6.48 \mathrm{cu}$. The mean alkalinity is equal to 5.52 c.u.

\subsection{Microbiological Analysis}

Bacteriological analysis of the soil of the site chosen

Table 2 Physicochemical parameters cocoa lixiviate.

\begin{tabular}{lllllllllllllll}
\hline Parameters & $\begin{array}{l}\mathrm{EC} \\
(\mu \mathrm{S} / \mathrm{cm})\end{array}$ & $\begin{array}{l}\mathrm{TDS} \\
(\mathrm{mg} / \mathrm{L})\end{array}$ & $\begin{array}{l}\mathrm{Cd} \\
(\mathrm{mg} / \mathrm{L})\end{array}$ & $\begin{array}{l}\mathrm{Cr} \\
(\mathrm{mg} / \mathrm{L})\end{array}$ & $\begin{array}{l}\mathrm{Fe} \\
(\mathrm{mg} / \mathrm{L})\end{array}$ & $\begin{array}{l}\mathrm{Zn} \\
(\mathrm{mg} / \mathrm{L})\end{array}$ & $\begin{array}{l}\mathrm{Cu} \\
(\mathrm{mg} / \mathrm{L})\end{array}$ & $\begin{array}{l}\mathrm{Mn} \\
(\mathrm{mg} / \mathrm{L})\end{array}$ & $\begin{array}{l}\mathrm{Ni} \\
(\mathrm{mg} / \mathrm{L})\end{array}$ & $\begin{array}{l}\mathrm{Cl}^{-} \\
(\mathrm{mg} / \mathrm{L})\end{array}$ & $\begin{array}{l}\mathrm{SO}_{4}{ }^{2-} \\
(\mathrm{mg} / \mathrm{L})\end{array}$ & $\begin{array}{l}\mathrm{NO}_{2}{ }^{-} \\
(\mathrm{mg} / \mathrm{L})\end{array}$ & $\begin{array}{l}\mathrm{PO}_{4}{ }^{2-} \\
(\mathrm{mg} / \mathrm{L})\end{array}$ & $\begin{array}{l}\mathrm{CO}^{2} \\
(\mathrm{mg} / \mathrm{L})\end{array}$ \\
\hline Concentrations & 53 & 53 & 0.00 & 0.00 & 5.882 & 3.438 & 0.866 & 0.578 & 0.906 & 0.00 & 31.91 & 0.0009 & 0.00 & 1649 \\
\hline
\end{tabular}

Table 3 Soil texture of the study area.

\begin{tabular}{llll}
\hline Composition & \multicolumn{3}{c}{ Depths } \\
\cline { 2 - 4 } & $0-3 \mathrm{~cm}$ & $3-20 \mathrm{~cm}$ & $20-40 \mathrm{~cm}$ \\
\hline Clay \% & 47.00 & 46.75 & 46.25 \\
Fine silt \% & 7.50 & 7.00 & 9.25 \\
Fat silt \% & 5.68 & 6.31 & 5.09 \\
Fine sand \% & 17.90 & 14.09 & 14.18 \\
Fat sand \% & 18.29 & 21.73 & 20.05 \\
Humidity \% & 3.09 & 4.49 & 6.71 \\
\hline
\end{tabular}


Table 4 Chemical components of the analyzed soil.

\begin{tabular}{|c|c|c|c|c|c|c|}
\hline \multirow{3}{*}{ Composition } & \multicolumn{6}{|c|}{ Depths } \\
\hline & \multicolumn{2}{|c|}{$0-3 \mathrm{~cm}$} & \multicolumn{2}{|c|}{$3-20 \mathrm{~cm}$} & \multicolumn{2}{|c|}{$20-40 \mathrm{~cm}$} \\
\hline & Av & Ap & Av & Ap & Av & Ap \\
\hline Humidity \% NF ISO 11465 & 3.09 & 7.30 & 4.49 & 5.80 & 6.71 & 4.50 \\
\hline \multicolumn{7}{|l|}{ Organic matter } \\
\hline *Total organic matter $\mathrm{g} / \mathrm{Kg}$ & 40.81 & 22.86 & 16.12 & 19.49 & 14.29 & 18.38 \\
\hline${ }^{*} \mathrm{C}$ org g/kg: NF ISO 14235 & 23.67 & 13.26 & 9.35 & 11.49 & 8.29 & 10.66 \\
\hline *Total nitrogen g/kg: NF ISO 11261 & 1.86 & 1.11 & 0.41 & 0.39 & 0.21 & 0.21 \\
\hline Phosphoric acid & & & & & & \\
\hline * P Sol mg/kg NF ISO 11263 & 25.98 & 11.97 & 5.35 & 7.17 & 6.39 & 4.50 \\
\hline \multicolumn{7}{|l|}{$\begin{array}{l}\text { Exchangeable acids } \\
\mathrm{Al}^{3+}\end{array}$} \\
\hline $\begin{array}{l}\mathrm{H}^{+} \\
\mathrm{Al}^{3+}+\mathrm{H}^{+}\end{array}$ & 0.00 & 0.00 & 0.00 & 0.00 & 0.00 & 0.00 \\
\hline \multicolumn{7}{|l|}{ Exchangeable bases } \\
\hline * CaO g/kg NF X31108 & 1.73 & 1.15 & 0.59 & 0.94 & 0.67 & 1.42 \\
\hline$* \mathrm{MgO}$ g/kg NF X31108 & 0.14 & 0.10 & 0.06 & 0.25 & 0.07 & 0.20 \\
\hline$* \mathrm{~K}_{2} \mathrm{O}$ g/kg NF X31108 & 0.28 & 0.33 & 0.26 & 0.052 & 0.30 & 0.079 \\
\hline$* \mathrm{Na}_{2} \mathrm{O}$ g/kg NF X31108 & 0.020 & 0.017 & 0.022 & 0.001 & 0.019 & 0.051 \\
\hline $\mathrm{S}$ (sum) $\mathrm{g} / \mathrm{kg}$ & & & & & & \\
\hline$* \mathrm{~T}(\mathrm{CEC}) \mathrm{cmol} / \mathrm{kg} \mathrm{X} 31130$ & 15.93 & 10.34 & 10.57 & 11.81 & 10.60 & 8.83 \\
\hline *water pH-1:5 : NF ISO 10390 & 6.84 & 6.60 & 6.23 & 6.73 & 6.18 & 6.53 \\
\hline${ }^{*} \mathrm{pKCl}-1: 5$ : NF ISO 10390 & 6.05 & 5.88 & 4.69 & 6.15 & 4.89 & 5.52 \\
\hline
\end{tabular}

for the study, each sampling show the presence of bacteria sought in surface $(0-3 \mathrm{~cm})$ and depth $(3-20 \mathrm{~cm})$. These groups of microorganisms are generally higher during the heap fermentation of cocoa compared to day 0 corresponding to the levy before fermentation.

3.3.1 Temporal Variations of the Total Flora (HMB) Abundances

The abundances of the total flora of the soil of the study site in the $0-3 \mathrm{~cm}$ depth ranged from $8.2 \times 103$ to $1 \times 103 \mathrm{CFU} / \mathrm{g}$ soil. The lowest abundance was observed on day 5 of the heap fermentation after $18 \mathrm{~h}$. The highest density was obtained on day 1 of the heap fermentation after $12 \mathrm{~h}$ in 3-20 cm depth (Fig. 1a). HMB abundances generally ranged from one day to another and from one sampling period to another. The lowest abundance $(0.85 \times 103 \mathrm{CFU} / \mathrm{g}$ soil $)$ was obtained on day 5 of the heap fermentation after $18 \mathrm{~h}$, while the highest abundance $(6.7 \times 103 \mathrm{CFU} / \mathrm{g}$ soil $)$ was observed on day 1 of the heap fermentation after the same incubation period (Fig. 1b).

3.3.2 Temporal Variations of Total Coliforms Abundances
The abundances of total coliforms in the soil of the site are very low before the heap fermentation of cocoa $\left(0.05 \times 10^{3}\right.$ and $0.06 \times 10^{3} \mathrm{CFU} / \mathrm{g}$ soil respectively in 0-3 cm and 3-20 cm depths). During the heap fermentation of cacao, these abundances increased in the ground and reach $4.6 \times 10^{3}$ and $4.5 \times 10^{3} \mathrm{CFU} / \mathrm{g}$ of soil in the $0-3 \mathrm{~cm}$ and $3-20 \mathrm{~cm}$ depths respectively. It was observed that during the fermentation, the presence of total coliforms was sometimes nil in few sampling periods (Fig. 2).

\subsubsection{Temporal Variations of Fecal Coliforms Abundances}

Fig. 3 shows the variation of fecal coliforms abundances in the soil of the study site during the sampling period. It appears that bacteria belonging to this group are present on the surface $(0-3 \mathrm{~cm})$ from the ground of the study site with low abundances $(0.004 \times$ $10^{3} \mathrm{CFU} / \mathrm{g}$ of soil). They are missing the depth (3-20 $\mathrm{cm})$. During the heap fermentation of the cocoa, the abundances of fecal coliforms in the soil ranged from 0 to $1.75 \times 10^{3} \mathrm{CFU} / \mathrm{g}$ soil observed respectively at day 


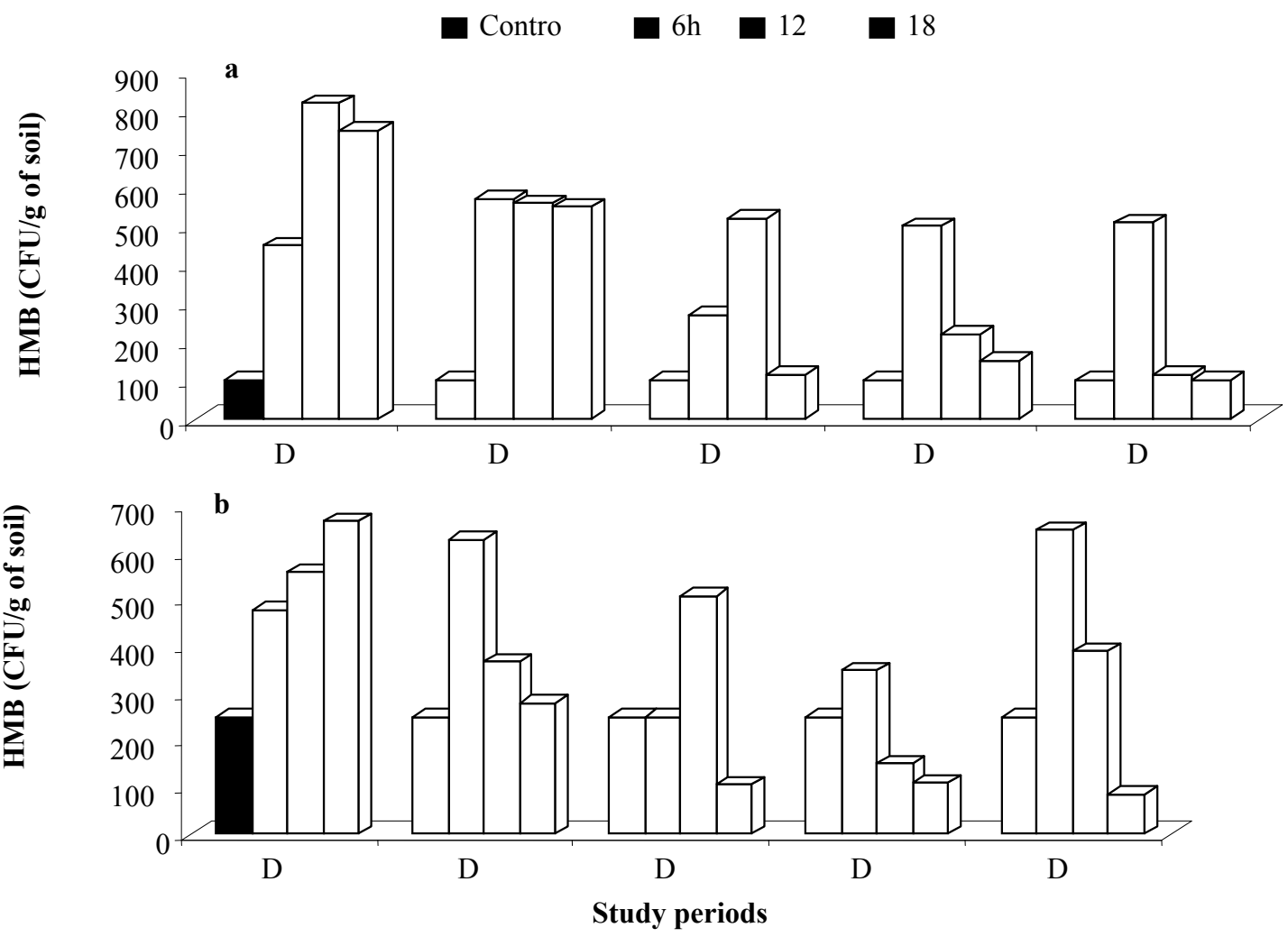

Fig. 1 Temporal variations of HMB abundances in the soil (a: $3 \mathrm{~cm} ; \mathbf{b : 2 0} \mathrm{cm})$.
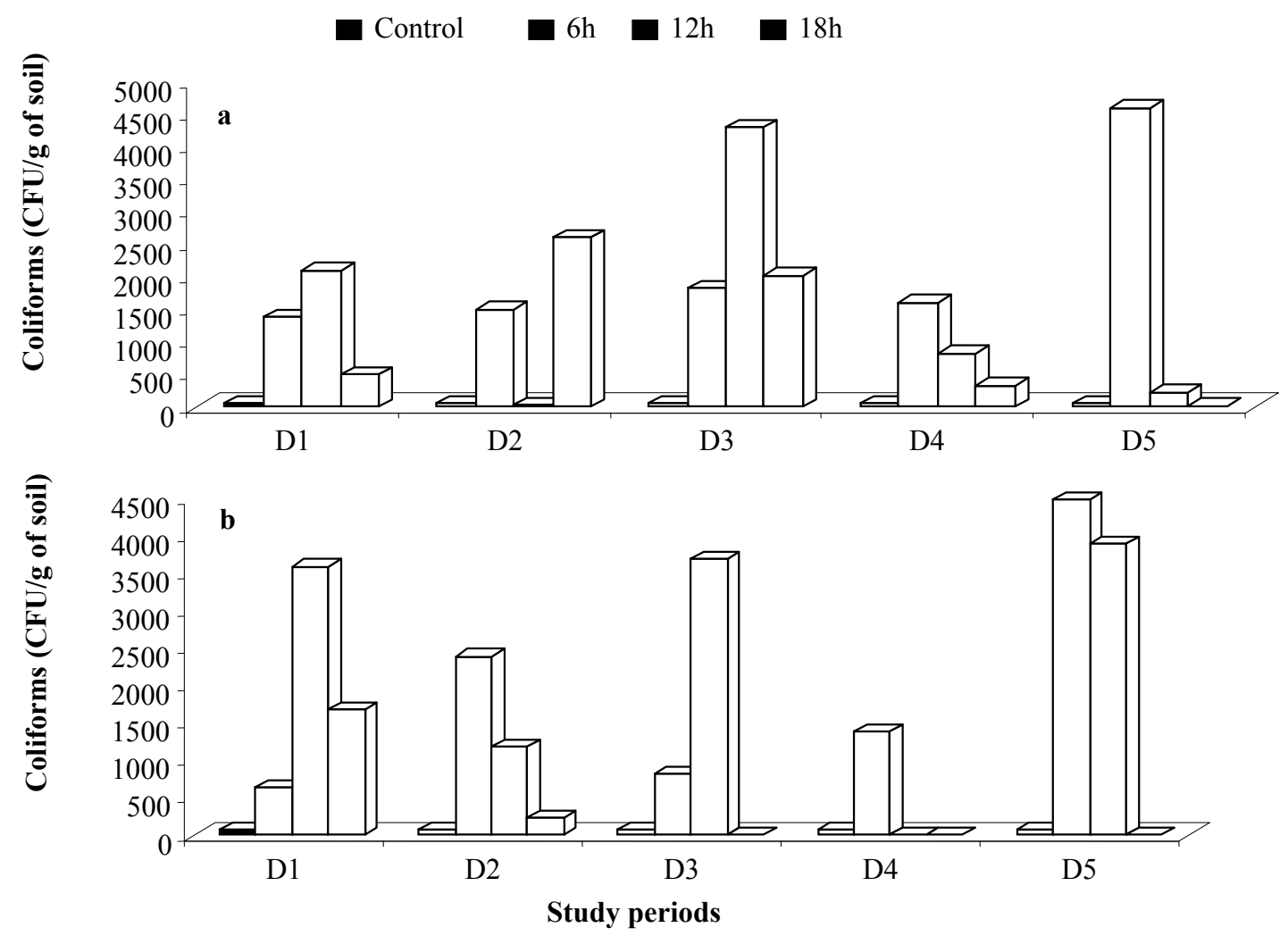

Fig. 2 Temporal variations of total coliforms abundances (a: $3 \mathrm{~cm} ; \mathbf{b : 2 0} \mathbf{c m})$. 


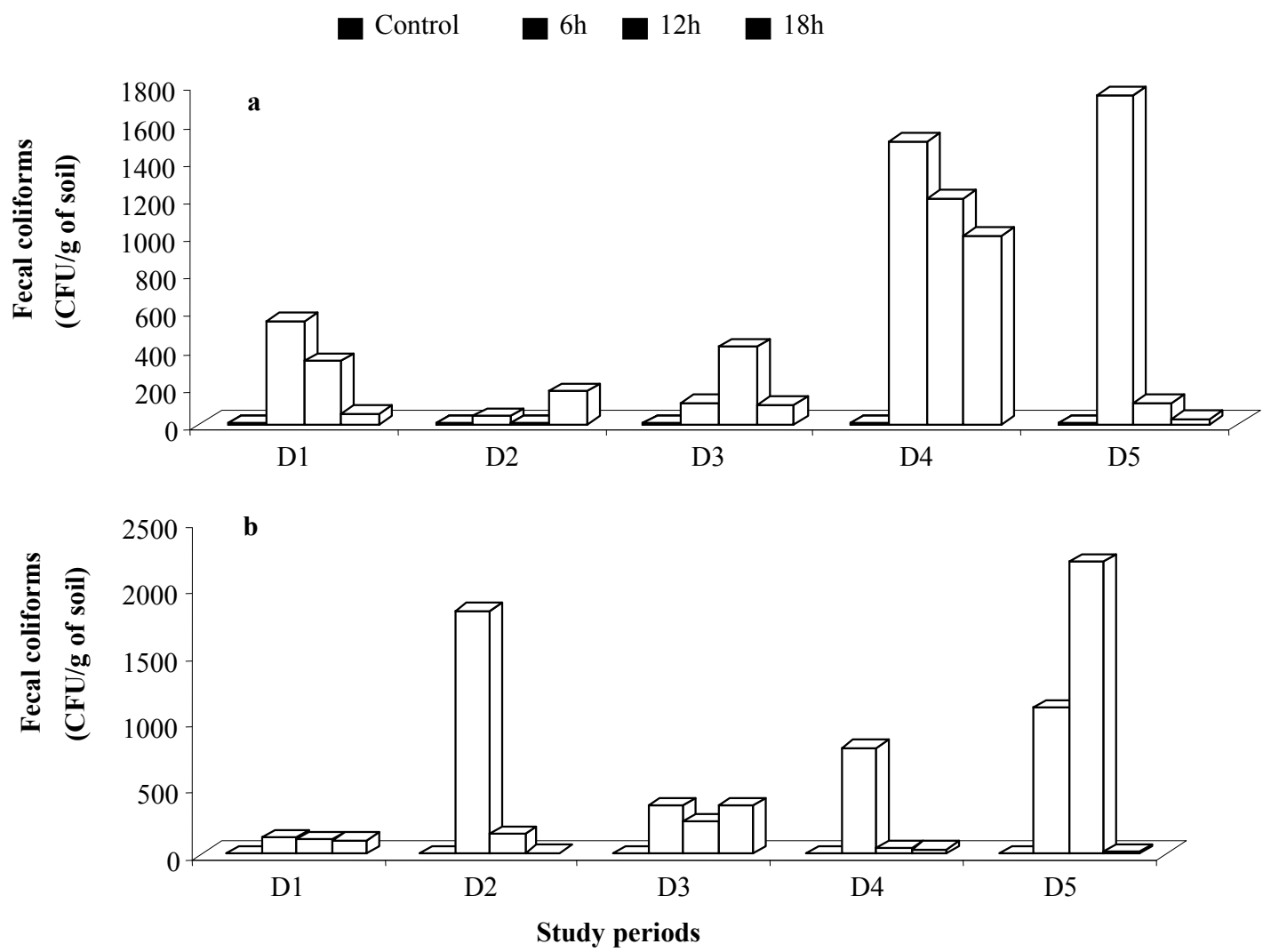

Fig. 3 Temporal variations of fecal coliforms abundances in the soil (a: $3 \mathrm{~cm} ; \mathbf{b : 2 0} \mathrm{cm})$.

2 after $12 \mathrm{~h}$ and at day 5 after $6 \mathrm{~h}$. In the 3-20 cm depth, the abundances of fecal coliforms ranged from $0.3 \times$ $10^{3}$ to $2.5 \times 10^{3} \mathrm{CFU} / \mathrm{g}$ soil. The lowest abundance was observed at 2, 4 and 5 days of heap fermentation of cocoa after $18 \mathrm{~h}$ while the highest density was obtained on day 5 after 12 h (Fig. 3).

3.3.4 Temporal Variations of Fecal Streptococci Abundances

Fecal streptococci abundances in the soil during the heap fermentation of the cocoa are higher than those registered on day 0 corresponding to the control. In general, streptococci abundances vary by soil sampling in one day and from one day to another.

In the $0-3 \mathrm{~cm}$ depth, the highest abundance was $0.6 \times 10^{3} \mathrm{CFU} / \mathrm{g}$ soil obtained on day 3 of heap fermentation after $6 \mathrm{~h}$ while at the 3-20 cm depth, the highest abundance was $0.51 \times 10^{3} \mathrm{CFU} / \mathrm{g}$ of soil observed on day 5 of the heap fermentation of cocoa after $12 \mathrm{~h}$ (Fig. 4).

\subsection{Temporal Variations of Yeast Abundances}

Microbiological analysis of the soil of the study site showed no yeast at all depths before the heap fermentation of cocoa. During the heap fermentation of the cocoa, the presence of yeasts was observed with oscillating abundances between $0.01 \times 10^{3} \mathrm{CFU} / \mathrm{g}$ of soil obtained on day 2 after $12 \mathrm{~h}$ and $3.5 \times 10^{3} \mathrm{CFU} / \mathrm{g}$ soil observed on day 3 after $18 \mathrm{~h}$. In the depth $3-20 \mathrm{~cm}$, yeast abundances ranged from $0.01 \times 10^{3}$ on day 2 after $12 \mathrm{~h}$ to $1.5 \times 10^{3} \mathrm{CFU} / \mathrm{g}$ of soil on day 4 after $6 \mathrm{~h}$ (Fig. 5).

3.4.1 Pearson " $r$ " Correlations between Depths and Cells Abundance Obtained on Days D1, D2, D3, D4 and D5.

Pearson " $\mathrm{r}$ " correlation coefficients between different depths and cell abundances obtained on days D1, D2, D3, D4 and D5 were calculated. It appears that no significant correlation $(P>0.05)$ was recorded between the different depths and cell abundances obtained on days D1, D2, D3, D4 and D5. 

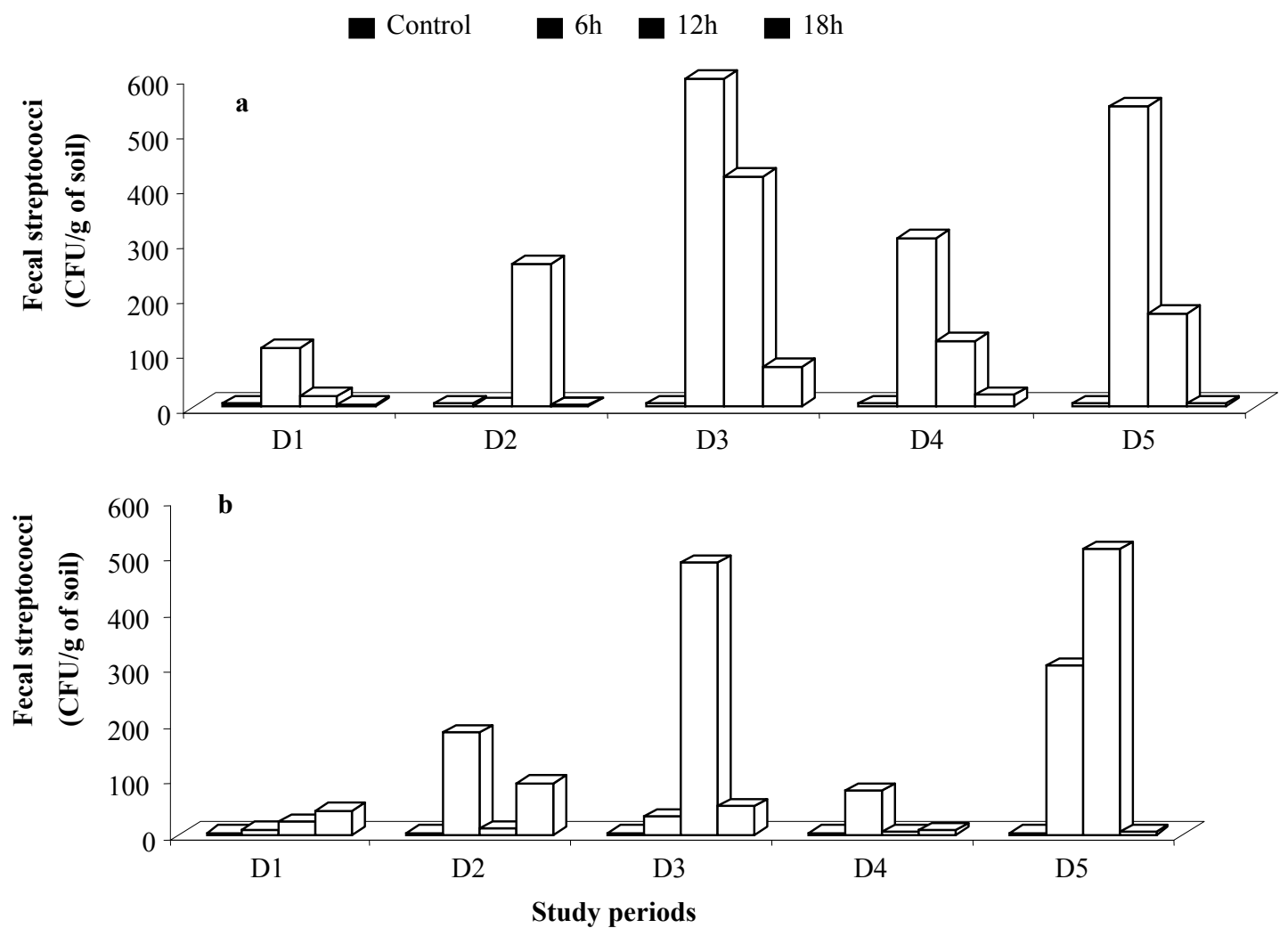

Fig. 4 Temporal variations of fecal streptococci abundances in the soil (a: $3 \mathrm{~cm} ; \mathbf{b : 2 0} \mathbf{c m})$.
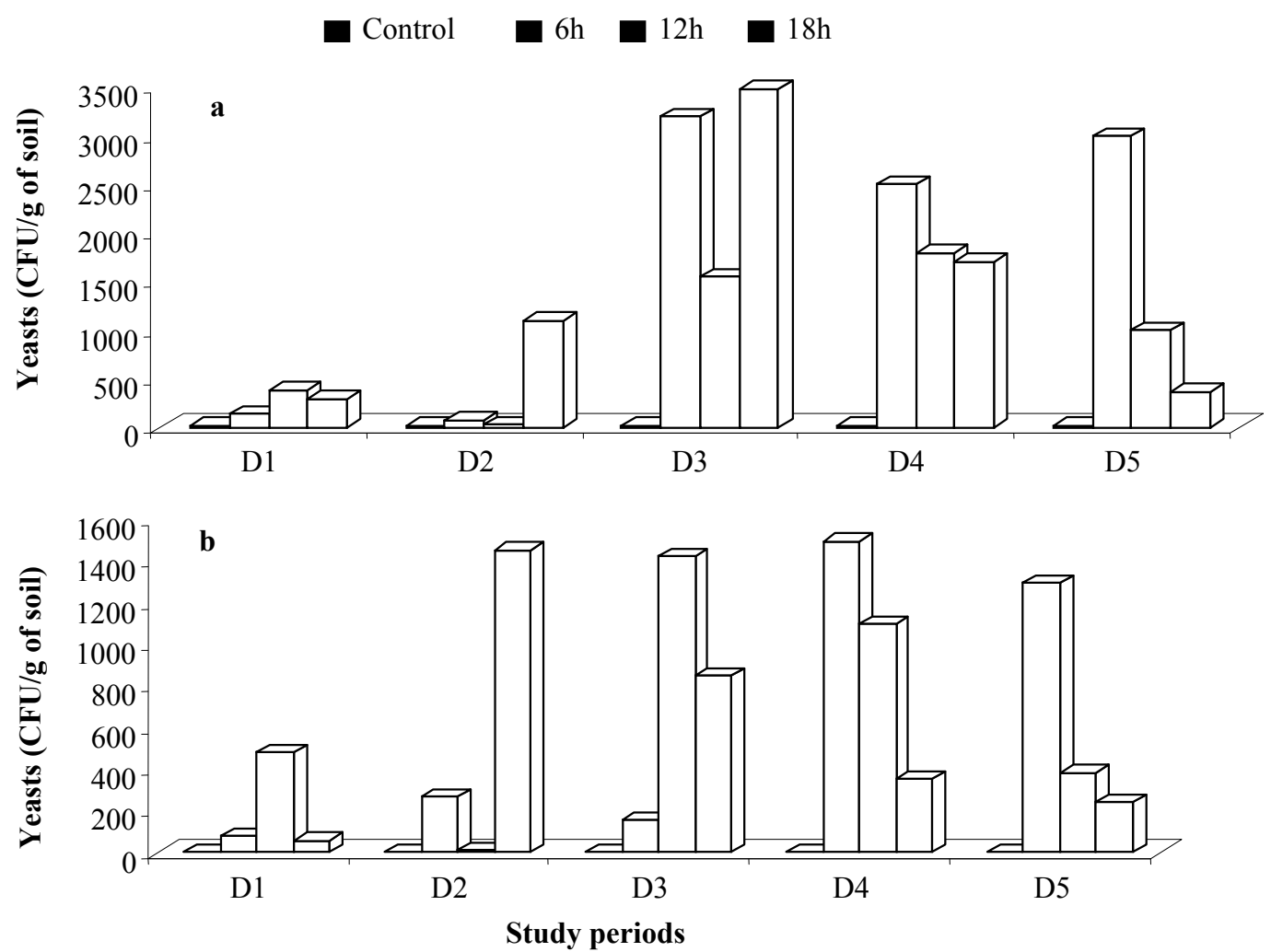

Fig. 5 Temporal variation of the yeast abundances in the soil $(\mathrm{a}: 3 \mathrm{~cm} ; \mathbf{b : 2 0} \mathbf{c m})$. 
3.4.2 Pearson " $\mathrm{r}$ " Correlations between Incubation Durations and Cell Abundances Obtained on Days D1, D2, D3, D4 and D5.

The Pearson " $r$ " correlation coefficients between incubation durations and cell abundances obtained on days D1, D2, D3, D4, and D5 were assessed and are presented in Table 5 below.

The Pearson " $r$ " correlation test has shown that there is no significant correlation $(P>0.05)$ between the incubation periods and the fecal streptococci, fecal and total coliforms abundances obtained on days D1, D2, D3, D4 and D5. On the contrary, significant correlations $(p \leq 0.05)$ were noted between incubation durations and BHAM, and yeasts abundances obtained on days D1 and D2 respectively.

3.4.3 Comparison of Mean Abundances Obtained on Days D1, D2, D3, D4, and D5 amongst the Incubation Periods

For each microorganism and each day of sampling, the mean abundances were calculated for each incubation period. The ANOVA test was used to compare the mean cell abundances amongst the different incubation periods. It appears from this comparison that overall there is a significant difference ( $p \leq 0.05$ ) amongst the mean cells abundance of HMB on days D1 and D3, of total coliforms on days D3 and D4 and yeasts on days D1 and D2.

3.4.4 Comparison of the Mean Abundances of HMB, FC, TC, FS and Yeasts Obtained amongst Days D1, D2, D3, D4 and D5

In general, for each microorganism, the mean cell abundances were calculated for each incubation period. The ANOVA test was used to compare the mean cell abundances amongst days of sampling. It shows that overall there is a significant difference $(p \leq 0.05)$ the mean cell abundances HMB between sampling days.

\section{Discussion}

The absence of yeast in the soil before the heap fermentation and their appearance after the beginning of the fermentation of cocoa may explain the origin of these microorganisms in the soil of the study site. Yeasts would come from cocoa lixiviate flowed into the soil at the time of heap fermentation. Studies show

Table 5 Pearson "r" correlations of between incubation durations and cell abundances obtained on days D1, D2, D3, D4 and D5.

\begin{tabular}{lllllllllll}
\hline $\begin{array}{l}\text { Microorganisms and } \\
\text { sampling days }\end{array}$ & \multicolumn{4}{c}{ HMB } & \multicolumn{4}{c}{ YEASTS } \\
\cline { 2 - 11 } & D1 & D2 & D3 & D4 & D5 & D1 & D2 & D3 & D4 & D5 \\
\hline Depths & $0.911^{* *}$ & 0.615 & 0.294 & -0.189 & -0.172 & 0.54 & $0.759 *$ & 0.546 & 0.326 & -0.069 \\
\hline
\end{tabular}

$\mathrm{ddl}=7 ; * *: P<0.01 ; *: P<0.05$.

Table 6 Comparison of the mean cell abundances obtained on days D1, D2, D3, D4 and D5 amongst incubation periods.

\begin{tabular}{llllll}
\hline Microorganisms & $\mathrm{D} 1$ & $\mathrm{D} 2$ & $\mathrm{D} 3$ & $\mathrm{D} 4$ & $\mathrm{D} 5$ \\
\hline HBM & $\mathrm{P}=0.024^{*}$ & $\mathrm{P}=0.118$ & $\mathrm{P}=0.006^{*}$ & $\mathrm{P}=0.065$ & $\mathrm{P}=0.055$ \\
Fecal streptococci & $\mathrm{P}=0.586$ & $\mathrm{P}=0.704$ & $\mathrm{P}=0.229$ & $\mathrm{P}=0.283$ & $\mathrm{P}=0.092$ \\
Fecal coliforms & $\mathrm{P}=0.348$ & $\mathrm{P}=0.495$ & $\mathrm{P}=0.271$ & $\mathrm{P}=0.394$ & $\mathrm{P}=0.278$ \\
Total coliforms & $\mathrm{P}=0.074$ & $\mathrm{P}=0.355$ & $\mathrm{P}=0.033^{*}$ & $\mathrm{P}=0.034^{*}$ & $\mathrm{P}=0.068$ \\
Yeasts & $\mathrm{P}=0.036^{*}$ & $\mathrm{P}=0.002^{*}$ & $\mathrm{P}=0.532$ & $\mathrm{P}=0.132$ & $\mathrm{P}=0.093$ \\
\hline
\end{tabular}

$\mathrm{ddl}=7 ; *: P<0.05$.

Table 7 Comparison of the mean abundances of HMB, FC, TC, FS and yeasts obtained amongst days D1, D2, D3, D4 and D5.

\begin{tabular}{llllll}
\hline Microorganisms & HMB & Fecal streptococci & Fecal coliforms & Total coliforms & Yeasts \\
\hline Probabilities & $\mathrm{P}=0.033^{*}$ & $\mathrm{P}=0.532$ & $\mathrm{P}=0.124$ & $\mathrm{P}=0.323$ & $\mathrm{P}=0.077$ \\
\hline
\end{tabular}

$\mathrm{ddl}=43 ; *: P<0.05$. 
that cocoa lixiviate contains yeast which at the time of heap fermentation convert cocoa juice into alcohol. Similarly, the temporal variation of abundance of bacteria studied in the soil sampling site is linked to the heap fermentation of cocoa, which not only causes an increase in the soil temperature suitable for bacterial metabolism but also provides the organic material contained in the cocoa juice (lixiviate). This organic material is used by microorganisms for their nutrition and multiplication.

The previous studies reports that up to $60 \mathrm{~cm}$ depth, the soil pores are soaked in water and act as an aero-anaerobic optional for bacteria. Thus, the total flora (HMB) was much easier to survive which may explain their higher abundance during the study [9]. In addition, the presence of these bacteria in the soil shows that the soil is an important matrix, from the standpoint that it contains a number and a large diversity of microorganisms at different depths [10].

Overall, it was observed that the concentrations of bacteria were higher after 6 and $18 \mathrm{~h}$ when the intensity of the UV rays of the sun has no effect. This could be explained by the bactericidal effect of these rays on bacterial cells [10].

These microorganisms can contribute to the improvement of soil fertility by the decomposition of organic matter and the release of inorganic compounds. Indeed, the nitrogen compounds are affected by nitrifying and denitrifying bacteria. Nitrate reduction by denitrifying bacteria in the presence of organic compounds in the suspended solids under anaerobic conditions, leading to the production of nitrites, which are then decomposed into elementary nitrogen. Under aerobic conditions, the ammonia that can be produced during the decomposition of organic matter is oxidized to nitrite and nitrate [11]. Likewise, the iron may be subject to reduction or oxidation depending on $\mathrm{pH}$ conditions or the redox potential of the water. At every moment, the metabolic potential of the microorganism is imposed by the duration of exposure to the donor or acceptor molecule electron, the microorganism residence period also influences metabolic potential [12].

The Pearson " $\mathrm{r}$ " correlation test made between different depths and cell abundances obtained on days D1, D2, D3, D4, and D5 were calculated and showed that no significant correlation $(P>0.05)$ was found between these different depths and cell abundances. Similarly, no significant correlation $(P>0.05)$ exists between the incubation durations and the fecal streptococci, fecal and total coliforms abundances obtained on days D1, D2, D3, D4 and D5. On the contrary, significant correlations $(p \leq 0.05)$ were noted between incubation durations and HMB and yeasts abundances obtained on days D1 and D2 respectively.

The ANOVA test revealed that a significant difference $(p \leq 0.05)$ exists globally amongst the mean abundances of HMB cells on days D1 and D3, Total Coliforms in the days D3 and D4 and yeasts in the days D1 and D2. Similarly, a significant difference $(P \leq 0.05)$ amongst the mean abundances of HMB cells was recorded between the different days of sampling.

\subsection{Physical Chemistry}

The mean $\mathrm{pH}$ values for agricultural soils range from 8.10 to 8.85 uc [2]. However, the $\mathrm{pH}$ values range between 6 and $6.85 \mathrm{uc}$. This is an acidic $\mathrm{pH}$ which is opposed to the results of Ben Hassine [13] found on soils of Fez in Morocco. This result could be explained by the presence of homes around the study site, and transformation of organic matter by microorganisms acid [14].

The relative humidity ranging between 3.09 and $7.30 \%$ during the study is lower than the recommended value for agricultural soils (12-20\%). Although heap fermentation increases the moisture content (Table 4), the method is not effective enough to restore adequate moisture. Similarly, the concentrations of nitrates, exchangeable cations, organic carbon and exchangeable bases remain higher than those recommended for agricultural soils (Table 4). For agricultural sites, nitrate values ranged from 34.2 to 
$530.7 \mathrm{ppm}$, respectively in the $0-3 \mathrm{~cm}$ depth, while in the second depth $3-20 \mathrm{~cm}$, the values fluctuated between 59.8 and $1,082.5 \mathrm{ppm}$. Nitrates generally come from the decomposition of plant or animal materials, fertilizers used in agriculture, manure, domestic and industrial wastewater and precipitations [15]. For these agricultural soils, total phosphorus concentration fluctuated between 17.88 and $221 \mathrm{ppm}$, and come from fertilizer application while the values of the exchangeable cations showed that these elements found in the study (Table 4) were present in trace [4].

\section{Conclusion}

The impact of the heap fermentation of the cocoa on microbial dynamics and physicochemical parameters of the soil was clearly discernible in this study. On the physical, mechanical analysis showed that the soil of the study site is comprised of clay, silt and sand. Chemically, before the heap fermentation of cocoa total organic matter of the analyzed soil had a net variation. Soil $\mathrm{pH}$ studied before the heap fermentation of cocoa is acid with an alkalinity of less than $6.1 \mathrm{uc}$ after fermentation of cocoa, organic matter concentration in the soil decreases the shallowest depth and increases to great depths. The total phosphorus content after fermentation has generally decreased at different depths. The abundances of the total flora of the soil in the study site vary throughout one depth to another. Those of total coliforms in the soil in the site were very low before fermentation and increase during fermentation of cocoa. The temporal variation of fecal coliforms in soil of the study during the sampling period site showed that bacteria belonging to this group were present on the surface of the study site with low abundances and were absent in depth. The abundances of fecal streptococci in the soil during the heap fermentation of the cocoa were higher than those registered on day 0 corresponding to the control. The absence of yeast at all depths before the beginning of the fermentation of cocoa was noted. On the contrary, during the heap fermentation of the cocoa the yeast were observed. The significant correlations were noted between incubation durations and HMB and yeasts abundances obtained on days D1 and D2 respectively. A significant difference was observed amongst the mean abundance of HMB cells on days D1 and D3, total coliforms on days D3 and D4 and yeasts on days D1 and D2. Similarly, a significant difference the mean abundances HMB cells were recorded amongst the different days of sampling.

\section{References}

[1] Antoine, F. 2001. La Pollution des sols: Impact sur L'environnement et la Santé: Note Rapide sur L'environnement et la Santé, 26.

[2] Rodier, J. 1996. L'analyse de l'eau: eaux Naturelles. Eaux Residuaires et Eaux de Mer. 8th edition. Paris: Dunod.

[3] Earth Sciences for Society Foundation.Octobre 2007. Pays-Bas:leyde. Le sol: Épiderme vivant de la terre. Les Géosciences au Service de L'humanité.

[4] APHA, AWWA, and WEF APHA. 1998. Standard Methods for the Examination of Water and Wastewater. 20th edition, 201.

[5] Noah Ewoti, O. V. 2012. "Rétention des Bactéries dans le sol et sur des Fragments de Roches en Milieu Aquatique: Influence du Type de Cellule et de Quelques Paramètres Chimiques de l'environnement." Ph.D. thesis, Université de Yaoundé I.

[6] Noah Ewoti, O. V., Nola, M., Moungang, L. M., Nougang, M. E., Krier, F., and Chihib, N. E. 2011. "Adhesion of Escherichia Coli and Pseudomonas Aeruginosa on Rock Surface in Aquatic Microcosm: Assessment of the Influence of Dissolved Magnesium Sulfate and Monosodium Phosphate.” Res. J. Environ. Earth Sci. 3 (4): 364-74.

[7] Marchal, N., Bourdon, J. L., and Richard, C. 1991. Culture Media for Isolation and Biochemical Identification of Bacteria. Doin ed. Paris.

[8] Pasteur, D. 1987. Milieux et Réactifs de Laboratoire. Microbiologie et Immunologie. $33^{\mathrm{e} e}$ édition. Paris: Diagnostics Pasteur.

[9] Powell, K. L., and Taylor, R. G. 2003. "Microbial Contamination of Two Urban Sandstone Aquifers in UK." Water Research 37: 339-52.

[10] Ouabib, C. 2010. Contamination Microbiologique. Physico-Chimique et Métaux Lourds des Sols de la Ville de Fès. Msc. Thesis, University of Fès ,Senegal.

[11] Alvarez-Martin, P., Florez, A. B., Barranco, H., and Mayo, B. 2008. "Interaction between Dairy Yeasts and Lactic 
Acid Bacteria Strains during Milk Fermentation.” Food Control 19: 62-70.

[12] Kaban, G., and Kaya, M. 2006. "Effect of Starter Culture on Growth of Staphylococcus aureus in Sucuk." Food control 17: 797-801.

[13] Hassine, H. B. 2006. Tunisie:Direction des sols. Nature Minéralogique et Rôle Nutritionnel des Argiles de Sols cEréaliers en Région Subhumide à Semi-Aride. Ministère de L'Agriculture et des Ressources Hydrauliques. 2080 Ariana.

[14] Holt, J. G., Krieg, N. R., Sneath, P. H. A., Staley, J. T., and Williams, S. T. 2000. Bergey's Manual of Determinative Bacteriology. 9th edition. Philadelphia: Lipponcott Williams et Wilkins.

[15] Rodier, J. 2009. L'analyse de L'eau. $12^{\mathrm{e}}$ édition. Revue et Corrigée. Paris: Dunod. 